\title{
ICARE Model Learning Video For Economic Mathematics Subject
}

\author{
Roza Thohiri ${ }^{*}$, Revita Yuni ${ }^{1}$, Pebri Hastuti ${ }^{1}$ \\ ${ }^{1}$ Economic Education, Universitas Negeri Medan, Indonesia \\ *Corresponding author. Email: rozatho@unimed.ac.id
}

\begin{abstract}
Learning videos are teaching materials that will help individual students understand the subject matter using interactive tools. It is quite important to use learning in the electronic-based learning paradigm to support students in the learning process. ICARE-based learning videos are able to evoke student behavior in the learning process, improve understanding skills, and independent learning abilities. The whole research attempts to develop an economic mathematics video-based ICARE learning that is valid, effective, and practical. This study is a method of research and development specific to the ADDIE model, involving analysis, design, development, implementation, and evaluation. Participants of this study include media specialists, content experts, and academics of economics. The methods used to determine the eligibility of the video include a feasibility assessment sheet by a content expert, media specialists, and a student answer survey for the use of the video. The results showed that the economic mathematics learning video developed based on ICARE was practical with an average score of 3.18 content experts, 3.20 media experts, and 3.14 academic lecturers, so the validity of the e-module developed was in the "Good" and valid range to use. The results of the student learning assessment have been achieved with a proportion of 85.71 percent in the category of strong performance criteria so that the video can be classified as effective and practical for use in learning.In this study, only a few videos were developed from some of the existing material. It is hoped that for further research to make videos with all materials and with models that are adapted to the material for which the video will be made. The video in this study uses an ICARE-based KKNI curriculum which is easy to understand for independent learning and is recommended for use by educators and students in mathematics economics courses.
\end{abstract}

\section{Keywords: Development, Video Learning, ICARE Model}

\section{INTRODUCTION}

The world is currently entering the era of the fourth world industrial revolution where information technology has become the basis of human life or commonly called the industrial revolution era 4.0. The era of the industrial revolution 4.0 requires different mathematics learning. Therefore, mathematics learning needs to be continuously developed. Mathematics learning has a very important role in facing the global era. Through good mathematics learning, students are enabled to gain various kinds of provisions in facing challenges in the global era. The ability to think critically, logically, carefully, systematically, creatively, and innovatively are some of the abilities that can be grown and developed through good mathematics learning.

Information and communication technology is prioritized in everyday life in the era of the industrial revolution 4.0, so that learning at universities must also be adapted to the demands of industrial revolution 4.0, strive for mathematics education that can form creative, innovative, and competitive generations so that innovation in usual learning methods is needed to be done by the lecturer. It is time for lecturers to leave learning methods that tend to prioritize memorization or just finding one correct answer to a question. At this time optimizing the use of technology as a learning aid is very necessary. Integrity of technology in learning has at least three positive impacts in mathematics learning, namely technology can improve mathematics learning achievement, technology can increase the effectiveness of teaching mathematics, and technological integrity can affect what and how mathematics should be studied and taught.

The use of technology as a tool for learning mathematics can be implemented with the use of learning media. Learning media is a messenger 
technology that can be used for learning purposes. In addition, learning media has various benefits, including helping lecturers in delivering their teaching materials, learning media is also seen as a communication tool that bridges abstract ideas with the real world. Currently, many kinds of learning media have developed, one of which is learning video media.

The instructional video media is media that presents audio and visuals that contain good learning messages that contain concepts, principles, procedures, knowledge application theory to help to understand a learning material. Learning videos have various benefits, including being able to combine text, images, music, sound, moving images (animation) in a mutually supportive unit. This means that information can not only be seen as printed output but can also be heard, forming simulations and animations that can arouse student interest in learning and have a high value of graphic art in its presentation. Learning videos can streamline the learning process, and can motivate students in learning mathematics. However, if the delivery in the learning video is not structured, the learning material will also be difficult for students to understand. Therefore we need an appropriate and structured stage in delivering the material in the learning video.

One of the structured stages is the ICARE Model. ICARE is a learning model that has 5 structured stages, where stages are: (1) Introduction or introduction, (2) Connection or relationship, (3) Application or application, (4) Reflection or reflection, (5) Extension or follow-up activities (Carni et al, 2017). Judging from the stages of the ICARE model, if it is applied in a learning video media, the characteristics of the ICARE Model-Based Learning Video are at the stage introduction or introduction where the purpose of the learning material and the benefits of studying the material for everyday life will be stated. Furthermore, at the stage connection, you will connect the material discussed with previous materials, it aims to recall the material that has been studied by students. Furthermore, at the stage application, it will be explained about the essence of the material in the learning video, at the stage reflection it will be discussed about examples of questions and how to solve them about the material in the video, and at the stage extension, there will be further practice questions that will be done later. by students to practice independently and increase their ability to work on questions.

If in the learning video the stages are structured, it will be easier for students to understand the learning material, and also because with the learning video students can repeat material that is not clear. Some learning materials that are suitable to be delivered using learning videos are material that is quite difficult for students to understand and material that is densely discussed. ICARE learning media can improve students' problem-solving abilities, and can create learning activities that direct students to think critically and creatively. The learning media, namely learning modules based on the ICARE model, showing that ICARE-based learning modules have very high completeness.

Based on the results of observations made by researchers at Unimed, learning videos in the learning process are still limited. Students only use the internet during the learning process and watch youtube whose material is sometimes different from what the lecturer gives, the existing videos are not good enough and unstructured. Currently, due to online learning, sometimes explanations from lecturers are difficult to understand, due to network constraints, and so on. If there are learning media other than modules in the form of learning videos, it will make it easier for students to understand learning, because written explanations become audio-visual. The advantages obtained by the presence of learning videos are that learning materials can be repeated as needed so that they will understand more about the material.

ICARE Model-Based Learning Videos on Mathematics are very rare. This may be one of the factors causing mathematics learning to be less than optimally understood by students. Therefore, it is necessary to develop an ICARE model-based learning video on mathematics material. In using this ICARE model-based learning video, it is necessary to add a supporting application as a discussion forum between lecturers and students. The supporting applications in question such as google classroom, youtube, Edmodo application, home study application, and so on are aimed at creating interaction between lecturers and students. In developing a learning video based on the ICARE model, it is necessary to apply certain media development procedures. In developing this media, the researcher used the ADDIE development procedure (Analysis, Design, Development, Implementation, Evaluation). Thus, it is very important to research "Development of ICARE-Based Learning Videos for Economic Mathematics Learning".

Based on the above background, several problems can be identified, namely learning outcomes and levels of understanding are still low, media in the online learning process is still limited, the use of media in the form of videos is still small and unstructured, and online learning is constrained by networks and video 
media is needed that can play repeatedly. Based on the identification of the problem, the formulation of the problem is whether development video-based ICAREvalid to use and whether development video-based $I C A R E$ - effective and practical to use.

\section{LITERATURE REVIEW}

\subsection{Development Research Development}

The research is also called research and development. According to [28], research methods development is a research method used to produce a certain product and by testing the effectiveness of those products. The research and development model is an attempt to develop educational products effective in the form of learning materials, media, strategies, or materials others in learning for use in schools, not for test theory. According to [18], research and development (research and development) aim to produce new products through the development process, research and development Research and Development ( $\mathrm{R} \& \mathrm{D})$ is a process or steps to develop a new product or improve existing products in the form of objects or devices (hardware), such as books, modules, teaching aids in the classroom or laboratories, or models of education, learning, training, guidance, evaluation, management, etc.

Development or In English, Research, and Development is method research used to produce a particular product, and test the effectiveness of the product. Based on the opinions of the four experts above, it can be concluded that research and development in the field of education and learning is a research model that aims to develop and validate educational products and learning to improve and develop quality effective education and learning. The product of the research model It is hoped that this can be used to improve and develop the quality of education and learning.

In development research, one of the development models is known, namely the ADDIE model. The ADDIE development model is a learning design model based on an effective and efficient system approach and an interactive process, namely the results of the evaluation of each phase can bring learning development to the next phase. The result of one phase is the initial product for the next phase. This model consists of 5 main phases or stages, namely 1) Analyze, 2) Design, 3) Develop, 4) Implement, 5) Evaluate (Evaluate).

\subsection{Learning Media}

Learning media are anything that can be used to convey messages or lesson content, stimulate students' thoughts, feelings, attention, and abilities so that they can encourage the teaching and learning process. Meanwhile, according to [27], teaching media is in the methodological component, as one of the learning environments adopted by the teacher. For a teacher to use educational media effectively, every teacher must be able to have sufficient knowledge and understanding of educational or teaching media. Teachers are required to always be creative and understand the needs of teaching as technology advances. In the following, knowledge and understanding of learning, media will be presented.

According to [12], knowledge and understanding of learning media a. Media as a communication tool to make the teaching and learning process more effective. b. The function of the media to achieve educational goals c. The intricacies of the learning process. $d$. The relationship between teaching methods and educational media. e. The value or benefits of educational media in teaching f. Selection and use of educational media. g. Various types of educational media tools and techniques. h. Media education in every subject. i. Innovation efforts in educational media. Thus, it can be concluded that the media is an inseparable part of the teaching and learning process to achieve educational goals in general and learning objectives in schools in particular.

\subsection{Learning Video}

Learning video, media is media that presents audio and visuals that contain good learning messages that contain concepts, principles, procedures, knowledge application theory to help to understand a learning material. Video is seen and heard learning material audiovisual that can be used to convey messages or subject matter. It is said to be seen to hear because the elements of hearing (audio) and visual or video elements (seeming) can be presented simultaneously. Video is learning material that is packaged via videotape and can be viewed through a video/VCD player connected to a television monitor [30]. Learning video media can be classified into media types audiovisual aids (AVA) or media that can be seen and heard. Usually, this media is stored in the form of a disc or tape. VCD media is a media with video storage and a recording system where the audio-visual signal is recorded on a plastic disk instead of a magnetic tape. Instructional video media as teaching materials aim 1) to clarify and facilitate the delivery of messages so that they are not too verbalized. 2) Overcoming the 
limitations of time, space, and the senses of students and instructors 3) Can be used appropriately and varied.

Produce learning videos that can increase the motivation and effectiveness of users, the development of learning videos must pay attention to the characteristics and criteria. The characteristics of instructional videos are: 1) Clarity of Massage (message clarity) With video media students can understand learning messages more meaningfully and information can be received as a whole so that information will automatically be stored in long-term memory and is retention. 2) Stand Alone. The videos developed do not depend on other teaching materials or do not have to be used together with other teaching materials. 3) User Friendly. Video media uses simple language, is easy to understand, and uses common language. The information display that appears is helpful and friendly to the user, including the ease with which the user can respond and access as desired. 4) Content Representation. The material must be truly representative, for example, simulation or demonstration material. Both social and design subject matter can be made into video media. 5) Visualization with media. The material is packaged in multimedia, which includes text, animation, sound, and video according to the demands of the material. The materials used are applicable, processed, difficult to reach, dangerous if directly put into practice, have a high level of accuracy. 6) Using high-resolution quality. Display in the form of video media graphics made with digital engineering technology with high resolution but support for every spec computer system. 7) Can be used classically or individually. Learning videos can be used by students individually, not only in school settings but also at home. It can also be used classically with a maximum number of 50 students, it can be guided by the teacher or simply listen to the narrative descriptions from the narrators already available in the program.

\subsection{ICARE Learning Model}

Preparation of lesson materials/sessions for active learning uses a very simple framework, called ICARE. The ICARE system includes five key elements of a good learning experience, which can be applied to children, learners, young people, and adults. Therefore, the ICARE system is very good to be applied not only in training wherever it is carried out but also in the learning process in schools. ICARE stands Introduction, Connection, Application, Reflection, and Extension. The use of the ICARE system provides an opportunity for the trainees or students to have the opportunity to apply what they have learned in the training. The following describes the ICARE framework in detail.
ICARE's Learning Model includes the 5 key elements of a learning experience (whether with children, young people, or adults). As the name implies, "ICARE" This study is an acronym for five words are: introduction (introduction), connection (connect), Application (apply), Reflection (reflects), and Extension (expanding and evaluation). The ICARE learning system was developed by the Department of Educational Technology, San Diago University (SDSU) United States. The stages in the learning system ICARE are described in detail below:

a) Stage One: Introduction. Introduction at this stage the teacher or facilitator establishes the content of the lesson to the students. This section should contain the objectives of the lesson and what will be achieved during the lesson. The introduction should be short and simple, informing the material to be presented with the material as a whole (context)

b) Second Stage: Connection. Most learning is a series with one competency developed based on previous competencies. Therefore, all good learning experiences need to start from what students already know, can do, and develop. Most of the learning is a series with one competency developed based on previous competencies, connecting new knowledge with previous knowledge can improve understanding and application. At this stage, namely: a) Dividing material into sub-topics to make it easier for students to understand new information. b) Linking information to tasks related to the real world and prior knowledge. c) Facilitating students with information gradually and continuously so that it is a meaningful learning series. d) Presenting the material to be given more pleasantly with various approaches and use of media.

c) Stage Three: Application. This stage is the most important part of learning. After students acquire new information or skills through the stage connection, they need to be allowed to practice and apply this knowledge and skills. The application part should last the longest of the lesson/session where participants work alone, not with the instructor, in pairs, or in groups to complete real activities or solve real problems using the information and new skills they have acquired. Learning is carried out interactively and applies the material taught to real problems that occur in everyday life. Usually, this activity is carried out through an active learning process, and a series of practices.

d) Stage Four: Reflection. This section provides a summary of lessons/sessions, while participants 
have the opportunity to reflect on what they have learned. The instructor's task is to assess the extent of learning success. Reflection or summary activities can involve group discussions where the instructor asks participants to make presentations or explain what they have learned. They can also do independent writing activities where participants write a summary of the learning outcomes. This reflection can also be in the form of a short quiz, in which the instructor asks questions based on the content of the lesson. An important point to remember in reflection is that the instructor needs to provide opportunities for participants to express what they have learned.

e) Fifth Stage: Extension. There are two main activities in this final stage. First, the teacher conducts a series of additional learning experiences that can enrich the knowledge that students have achieved. Second, as a form of evaluation activity, namely the extent to which students can master the material that has been taught by the teacher. In schools, it is an extension usually called homework. Activities Extension may include providing additional reading material, research assignments, or exercises.

\section{RESEARCH METHOD}

This research was conducted at Unimed, Faculty of Economics, Accounting Education Study Program. This research was carried out in 2021. The subjects of this research were Unimed students, and experts in the fields of materials, media, and learning as well as economics mathematics lecturers. The object of this research is the development of ICARE-based video. The research method used by the researcher is the research and development method Research and Development (R\&D). This research is research that is used to produce certain products, and test the effectiveness of these products.

In this study, we will develop a product in the form of a video an-based on ICARE economics subjects. The development model used to develop the video is the ADDIE model which was developed to design a learning system. The research stages of developing the ADDIE model are (1) Analysis, (2) Design, (3) Development, (4) Implementation, and (5) Evaluation. The ADDIE model was developed to design a learning system.

Data collection can be done in various settings, various sources, and in various ways. However, in this study, researchers used data collected in terms of the way which is usually done by observation (observations), interviews (interviews), questionnaires, and (questionnaires), [28]. Questionnaires were created and used for material experts, media, and lecturers in terms of the feasibility of content, language, presentation, graphics, and ICARE model aspects.

The data analysis technique used in this research is the descriptive analysis technique. This data analysis analyzes the feasibility of the module from the results of filling out questionnaires by media experts, material experts, lecturers, and student responses to the video. The results of the analysis of the data obtained are used as a reference in improving the development video.

\section{RESULTS AND OUTCOMES}

\subsection{Stage Analysis}

\subsubsection{Needs Analysis}

At this stage, the researcher conducted a curriculum analysis which was carried out in the economics mathematics course at the Economics Education Study Program, Unimed Faculty of Economics, for the 20202021 academic year. The curriculum used is the national qualification framework curriculum (KKNI). The Indonesian National Qualifications Framework (KKNI) is a competency qualification tiering framework that can juxtapose, equalize, and integrate the education and job training fields as well as work experience to provide recognition of work competencies following the work structure in various sectors. The IQF curriculum requires learning outcomes consisting of attitudes, values, rights and responsibilities, abilities in the field of work, knowledge mastered, and managerial abilities.

\subsubsection{Analysis of Student Character and Abilities}

At this stage, the researchers analyzed the characteristics and abilities of the first-semester students of the Unimed Faculty of Economics. The purpose of this analysis is to examine the characteristics of students which include background knowledge, language used, cognitive, and independent learning abilities of students. The results of the study are used as a consideration for developing the video. From the results of the analysis, researchers obtained data about the character of new students, environmental changes from high school students to university students affect the ability to learn, and the differences in learning activities that have occurred so far. The language used during the learning process is Indonesian. The cognitive abilities of students are still not uniform, this can be seen from the difference in majors when in high 
school, there are those majoring in Science, Social Sciences, Language, and other majors whose basic mathematical abilities are different. Independence in learning is also an important point because when there are still many high schools that are not independent in the learning process, this can be seen from the dependence of students on lecturers to provide material and explanations. From the results of this analysis, the researcher then designed a video that was easy to understand, with simple language and so that it could be used independently.

\subsubsection{Analysis of the Use of Teaching Materials}

Lectures are currently conducted online, so additional media alternatives are needed to increase student understanding. Because the learning process is no longer bound by place and time, learning videos are needed that can be used whenever needed. Lecturers and students stated the need to develop more interesting videos, can clarify the material presented, and make it easier for students to understand the material independently and can be used with a computer, laptop, or cell phone media. Therefore, researchers developed video learning that can be used independently. In the development of video, we will discuss material about basic mathematical concepts and their application in economics, linear and non-linear functions and their application in economics, differential and integral and their application in economics, dynamic equations and deferential, exponential functions, growth, and differential equations, and financial mathematics. in the economic field.

\subsection{Stage Design}

\subsubsection{Outline Design Video}

The outline of the content of the video contains an initial design of the content to be presented and the order in which the material is presented. Following the analysis carried out, the researchers designed a video based on ICARE. In detail, it can be described as follows:

a) Introduction. Here the researcher designs an opening video containing the title, purpose of the learning video, and learning outcomes after watching this video.

b) Connection. Here the researcher designs a connection video that contains a discussion of the previous material divides the material that will be in the video and connects the video material with the real world.

c) Application. Here the researcher designs the main content of the material presented in the video. d) Reflection. In this section, the researcher designs a reflection that contains a summary and conclusion of the video material.

e) Extension. Contains additional knowledge and evaluations or assignments that can be done after watching this video.

\subsection{Development Stage}

At the development stage, a video that has designed an assessment or validation by subject matter experts, experts, and lecture of mathematics learning model economy. The assessment instrument is used to measure the feasibility (validity) of the video. The validator of the material expert assessment instrument is Dr. Dede Ruslan, M.Sc. The instrument validator for the expert assessment of the learning model is Dr. Khairuddin E. Tambunan, S. Sos., M.Si, and the lecturer validator is Putri Sari Silaban, SE, M.Sc. The results of the instrumented assessment that have been filled in by experts can be seen below:

Table 1. Validation Results Video

\begin{tabular}{|c|l|c|c|c|c|}
\hline No & $\begin{array}{c}\text { Aspects of } \\
\text { Assessment }\end{array}$ & $\begin{array}{c}\text { Expert } \\
\text { Material }\end{array}$ & $\begin{array}{c}\text { Expert } \\
\text { Learning } \\
\text { Media }\end{array}$ & Lecturer & Category \\
\hline 1 & Content & 3,20 & 3,30 & 3,10 & Valid \\
\hline 2 & Language & 3,20 & 3,50 & 3,20 & Valid \\
\hline 3 & Presentation & 3,20 & 3,00 & 3,40 & Valid \\
\hline 4 & Graphics & 3.40 & 3.00 & 3.00 & Valid \\
\hline 5 & ICARE & 2.90 & 3.20 & 3.00 & Valid \\
\hline $\begin{array}{l}\text { Overall Average } \\
\text { Score }\end{array}$ & $\mathbf{3 . 1 8}$ & $\mathbf{3 . 2 0}$ & $\mathbf{3 . 1 4}$ & Valid \\
\hline
\end{tabular}

The suggestions or inputs received by the authors from the results of the assessment are as follows:

Table 2. Suggestions and Inputs Expert Validator

\begin{tabular}{|l|l|l|c|}
\hline No. & Expert & \multicolumn{1}{|c|}{$\begin{array}{c}\text { Suggestions and } \\
\text { Feedback for }\end{array}$} & Improvement \\
\hline 1 & $\begin{array}{l}\text { Material } \\
\text { Expert }\end{array}$ & $\begin{array}{l}\text { - Explanation too fast } \\
\text { - More detailed and } \\
\text { organized material }\end{array}$ & $\begin{array}{l}\text { - Explanations have } \\
\text { been adjusted to the } \\
\text { rhythm like face to } \\
\text { face } \\
- \text { The material has } \\
\text { been added }\end{array}$ \\
\hline
\end{tabular}




\begin{tabular}{|c|c|c|c|}
\hline 2 & $\begin{array}{l}\text { Learning } \\
\text { Media } \\
\text { Experts }\end{array}$ & $\begin{array}{l}\text { - Sounds and music } \\
\text { don't sound in sync } \\
\text { - Unorganized } \\
\text { material movement } \\
\text { - In the Connection } \\
\text { section that } \\
\text { connects the } \\
\text { material to the real } \\
\text { world, there are still } \\
\text { fewer examples }\end{array}$ & $\begin{array}{l}\text { Sound and music } \\
\text { have been synced } \\
\text {-Transfer of } \\
\text { material has been } \\
\text { better organized - } \\
\text { Examples of } \\
\text { material and real- } \\
\text { world cases have } \\
\text { been added }\end{array}$ \\
\hline 3 & Lecturers & $\begin{array}{l}\text { - Some explanations } \\
\text { are lacking and } \\
\text { examples of } \\
\text { questions that are } \\
\text { still not understood }\end{array}$ & $\begin{array}{l}\text {-Explanations have } \\
\text { been added and } \\
\text { explanations of } \\
\text { questions have been } \\
\text { corrected }\end{array}$ \\
\hline
\end{tabular}

\subsection{Implementation Stage}

After the video is validated by experts and is fixed, the video is tested and implemented in the form of evaluation one by one to nine students in the category of low, medium, and high academic ability. Students who become objects are students of economic education in semester 1, the academic ability seen is the result of the mid-semester exam. Videos can be viewed using the watch application on mobile phones and computers. The test results are used as a reference in improving video the developed.

The trial was carried out separately for each student by observing and in-depth interviews on the use of economic mathematics videos. Students as respondents gave an assessment response to videos-based ICARE in economics mathematics courses based on aspects of learning clarity, impact on use in learning, and video feasibility. The results of the response to the video can be seen in the table below:

Table 3. Results of Assessment of Student Responses to Videos

\begin{tabular}{|l|l|c|c|c|}
\hline No & \multicolumn{1}{|c|}{$\begin{array}{c}\text { Aspects of } \\
\text { Assessment }\end{array}$} & Yes & No & $\begin{array}{c}\text { Percentage } \\
\text { Yes }\end{array}$ \\
\hline 1 & Learning Clarity & 7 & 2 & $77.8 \%$ \\
\hline 2 & Impact of Use & 7 & 2 & $77.8 \%$ \\
\hline 3 & Feasibility & 8 & 1 & $88.9 \%$ \\
\hline \multicolumn{4}{|c|}{ Total Percentage } & $\mathbf{8 1 . 5 \%}$ \\
\hline
\end{tabular}

The results of the assessment of student responses to the video in the completed questionnaire obtained an average overall score of $81.5 \%$ stating that the video has learning clarity, has an impact in helping them learn, and is suitable for use as lecture material to achieve learning objectives.

\subsection{Evaluation Stage}

At the evaluation stage, a limited trial was conducted by a small group of students. A limited trial of the-based economic mathematics video was ICARE conducted on 40 students in class A of the Accounting Education Study Program, Faculty of Economics, Medan State University. The trial serves to assess the practicality and effectiveness of the video by students as users. Practicality can be seen from the practicality questionnaire distributed to students to see the ease, usability, and effectiveness of time in using video. The effectiveness of the video can be seen from student activities during the learning process and learning outcomes using videos.

\subsubsection{Video Practicality}

The video practicality assessment is assessed by students as users. The practicality of-based videos were ICARE assessed by 40 students of class A of the Accounting Education Study Program who were the subjects of video trials. The results of the data analysis can be seen in the table below.

Table 4. Results of the practicalities of Student

\begin{tabular}{|c|l|c|c|}
\hline No & \multicolumn{1}{|c|}{ Variable } & $\begin{array}{c}\text { achieving the } \\
\text { Rate }(\%)\end{array}$ & Category \\
\hline 1 & Learnability & 81.20 & Practical \\
\hline 2 & Efficiency & 80.60 & practical \\
\hline 3 & $\begin{array}{l}\text { Effectiveness } \\
\text { of time }\end{array}$ & 82.10 & practically \\
\hline \multicolumn{2}{|l}{ average } & $\mathbf{8 1 . 3 0}$ & practical \\
\hline
\end{tabular}

The results of the analysis of the practicality assessment by students are 1) easy for users (Learnability) with an achievement level of $81.20 \%$ categorized as-based video ICARE practical for users, 2) efficiency with the degree of achievement $80.60 \%$ categorized as practical to use in the learning process, 3 ) effectiveness of time (effectiveness of time) with a degree of achievement of $82.10 \%$ categorized thatbased videos ICARE practical can streamline time in the learning process. The value of video practicality by students with an achievement level of $81.30 \%$ and videos can be categorized as practical.

\subsubsection{Video Effectiveness}

The effectiveness assessment serves to observe the effectiveness of the videos used in the learning process. 
To get the effective results of-based videos ICARE, observations were made of student activities during the learning process and learning outcomes. Video trials were conducted during two online meetings. The average activity of the results of observational analysis for the category of student activity during the learning process with an achievement level of $86.73 \%$ is categorized as an active student. The results of each category from the two meetings can be seen in the table below.

Table 5. Results of Degree Achievement of Student Activities

\begin{tabular}{|l|l|l|l|}
\hline No & $\begin{array}{l}\text { Category of student } \\
\text { activity by the observer }\end{array}$ & $\begin{array}{l}\text { \% } \\
\text { DP }\end{array}$ & Criteria \\
\hline 1 & $\begin{array}{l}\text { Watching videos and doing } \\
\text { exercises }\end{array}$ & 80.10 & Active \\
\hline 2 & $\begin{array}{l}\text { Students asking questions } \\
\text { after watching the video }\end{array}$ & 81.30 & Active \\
\hline 3 & $\begin{array}{l}\text { Answering questions from } \\
\text { lecturers and other students }\end{array}$ & 80.00 & Active \\
\hline 4 & Conclude learning & 81.50 & Active \\
\hline 5 & Completed task & 95.00 & $\begin{array}{l}\text { Active } \\
\text { once }\end{array}$ \\
\hline Average Overall & $\mathbf{8 5 . 5 8}$ & Active \\
\hline
\end{tabular}

Learning outcomes are seen from the value of the final semester exam (UAS). 35 students passed, and 5 students did not pass. The percentage of students who passed was $87.5 \%$ and $12.5 \%$ of students who did not pass. From the evaluation results, based on the theory that has been determined the learning process is effective because more than $80 \%$ of students pass the final semester exam. From the results of student activity and evaluation, ICARE-based economic mathematics videos are categorized as effective as learning resources.

\section{CONCLUSION AND SUGGESTIONS}

\subsection{Conclusion}

Based on the results of research and discussion of ICARE-based videos, it can be concluded as follows:

a) This development research produces teaching materials in the form of videos-based ICARE in the Mathematics-Economics course that can be viewed on computers and mobile phones. This study refers to the ADDIE development model with the stages of Analysis, Design, Development, Implementation, and Evaluation. b) The results obtained indicate that the video-based on ICARE economics mathematics developed is valid and feasible to be used as teaching materials for lecturers and students in the process of learning activities based on the acquisition of the average overall score of aspects by material and media experts of 3.18 and 3.2. with a valid category, and by a mathematics economics lecturer 3.14 with a good category, with an overall average score of 3.17 which means that video-based ICARE the resulting is valid to be used for learning.

c) The research shows that the percentage of practical use by students is $81.30 \%$, meaning that videosbased ICARE of economic mathematics is practically used in learning. The results of student activities on average are $85.58 \%$, which means that students are active in learning activities using videos -based ICARE economic mathematics, and the passing rate in the midterm exam is $85.71 \%$ which falls into the category of high success criteria, so it can be said videos-based are ICARE practical and effective for use in learning economics mathematics for both individuals and groups and are used in independent learning.

\subsection{Suggestions}

Suggestions given are based on the results of research conducted, among others:

a) It is hoped that this video for -based ICARE learning economics mathematics can be used by lecturers of economics mathematics courses in all study programs at the economics faculty

b) Further research can make videos of learning materials with other models that are following each criterion of economic mathematics learning material.

c) The development of further research results can integrate learning videos, e-modules, and evaluation of learning outcomes in one android or ios-based application that can be used by students and lecturers as well as helping more students in economics mathematics courses.

\section{REFERENCES}

[1] Arends, Richard, Learning To Teach, Ninth Edition.United States: Library of Conggres Catalonging-in-Publication Data. 2012.

[2] Arikunto, Suharsini. Prosedur Penelitian. Jakarta: Rineka Cipta. 2014.

[3] Branch, R. M. Intructional design: the ADDIE approach. University of Georgia. 2009. 
[4] Budi, Erinawati. Pengembangan E-Modul Penggabungan Dan Pemberian Efek Citra Bitmap Kelas Xi Multimedia SMK Negeri 1 Klaten. Universitas Negeri Yogyakarta. 2006.

[5] Darmawan, Deni. Teknologi dan informasi. Bandung: PT. Remaja Rosdakarya. 2014.

[6] Daryanto. Menyusun Modul. Yogyakarta: Gava Media. 2013.

[7] Depdiknas. Pedoman khusus penyusunan modul sekolah menengah atas. Direktorat Pendidikan Menengah Umum, Depdiknas. 2004.

[8] Depdiknas, Panduan Praktis Penyusunan EModul Pembelajaran. Jakarta: Direktorat Pembinaan SMA. 2017.

[9] Dwiki, dkk. Pengembangan E-Modul Dengan Model Problem Based Learning Pada Materi Bilangan Bulat Kelas VII. Jurnal Pendidikan Ekonomi. Vol. 14/no.2/2014.

[10] Evi, dkk. Pengembangan E-Modul Pembelajaran Ekonomi Materi Pasar Modal Untuk Siswa Kelas XI IPS MAN 1 Jember Tahun Ajaran 2016/2017. Jurnal Pendidikan Ekonomi. Vol. 12/no.2/2018.

[11] Farenta, A., Sulton, dan Satyosari, P. Pengembangan E-Module Berbasis Problem Based Learning Mata Pelajaran Kimia Untuk Siswa Kelas X SMA Negeri 8 Malang. Jurnal Pendidikan. Vol. 1/no.6/2016.

[12] Hamalik, Oemar. Proses Belajar Mengajar. Jakarta: Bumi Aksara. 2011.

[13] Istarani. Model Pembelajaran Inovatif. Medan: Media Persada. 2015.

[14] Komang, dkk. Pengembangan E-Modul Berbasis Model Pembelajaran Discovery Learning Pada Mata Pelajaran "Sistem Komputer" Untuk Siswa Kelas X Multimedia SMK Negeri 3 Singaraja. Jurnal Pendidikan Teknologi dan Kejuruan. Vol. 14/no.1/2017

[15] Nelvy, dkk. Pengembangan E-Module Ekonomi Pada Materi Uang Dan Perbankan Untuk Siswa Kelas X A SMA Negeri 1 Panggul Trenggalek Tahun Ajaran 2014/2015. Jurnal Pendidikan Ekonomi. Vol. 8/no.1/2015.

[16] Mardapi, Djemari. Teknik Penyusunan Instrumen Tes dan Non Tes. Yogyakarta: Mitra Cendekia Press. 2008.

[17] Mudhlofir, Ali. Aplikasi Pengembangan Kurikulum Tingkat Satuan Pendidikan dan Bahan Ajar dalam Pendidikan Agama Islam. Jakarta: Rajagrafindo. 2011.
[18] Mulyatiningsih, Endang. Metode Penelitian Terapan Bidang Pendidikan. Bandung: Alfabeta. 2013.

[19] Mulyasa. Kurikulum berbasis kompetensi: konsep, karakteristik, dan implementasi. Cetakan kesebelas. Bandung: PT Remaja Rosdakarya. 2008.

[20] Nasution. Berbagai Pendekatan dalam Proses Belajar \& Mengajar. Jakarta: PT Bumi Aksara. 2005.

[21] Prastowo, A. Panduan Kreatif Membuat Bahan Ajar Inovatif. Yogyakarta: DIVA Press. 2012.

[22] Purwoko, Agung. Kegiatan Belajar Mengajar (Buku Paket PPL). Semarang: UNNES Press. 2001.

[23] Rabiatun, dkk. Pengembangan E-Module IPS Dengan Pendekatan Kontekstual Untuk Siswa Kelas VII SMPK Mater Dei Probolinggo. Jurnal Pendidikan. Vol. 1/no.9/2016.

[24] Rusman, Model-Model Pembelajaran: Mengembangkan Profesionalisme Guru, Jakarta: Rajawali Pers. 2010.

[25] Slameto, Belajar dan Faktor-Faktor Yang Mempengaruhinya. Bandung: Rineka Cipta. 2012.

[26] Supratowo. Mengembangkan Bahan Ajar dengan Menyusun Modul. 2009

[27] Sudjana, N. Penilaiam Hasil Proses Belajar Mengajar, Bandung, PT.Remaja Rosdakarya. 2009.

[28] Sugiyono. Metode Penelitian Kuantitatif, Kualitatif, $R \& D$. Bandung: Alfabeta. 2016.

[29] Sukirno, Sudoni. Mikro Ekonomi Teori Pengantar. Jakarta: Raja Grafindo Persada. 2005.

[30] Sungkono. Pengembangan Instrumen Evaluasi Media Modul Pembelajaran. Artikel Ilmiah Tugas Akhir. Universitas Negeri Yogyakarta. 2012.

[31] Suseno, Bronto. Meningkatkan Aktivitas Belajar Siswa yang Berdampak Pada Hasil Belajar Menggunakan Metode Mastery Learning Discovery Berbasis Komik Matematika. Semarang: Universitas Negeri Semarang. 2007.

[32] Thohiri, Roza, dkk. Modul Berbasis Problem Based Learning Pada Mata Kuliah Perpajakan. Medan. Universitas Negeri Medan. 2018. 
[33] Trianto, Mendesain Model Pembelajaran Inovatif-Progresif: konsep, landasan, dan implementasinya pada kurikulum tingkat satuan penidikan (KTSP). Jakarta: Kencana Pranada Medi Group. 2009.
[34] Trianto, Mendesain Model Pembelajaran Inovatif-Proresif. Jakarta: Prenada Media. 2011. 